\title{
Permainan Tradisional Edukatif "Mpaá Ncimi” Sebagai Metode Untuk Meningkatkan Kemampuan Motorik Dan Perilaku Sosial
}

\author{
Anak \\ Sri Hardiningsih ${ }^{1}$, Muh. Rijalul Akbar ${ }^{2}$ Nurrahmah $^{3}$ \\ STKIP Taman Siswa Bima ${ }^{1,2,3}$ \\ sryhardiningsih@gmail.com ${ }^{1}$, muhrijalulakbar@gmail.com², \\ nurrahmah_mechyuny@yahool.com.id ${ }^{3}$
}

\begin{abstract}
Abstrak
Dalam menstimulasi perkembangan motorik anak, baik motorik halus maupun motorik kasar dapat menggunakan permainan. Permainan dalam pembelajaran bagi anakjuga dapat menumbuhkan rasa senang, bahagia dan mengembangkan perilaku sosial. Penelitian tentang "Permainan Tradisional Edukatif "Mpaá Ncimi”sebagai Metode untuk Meningkatkan Kemampuan Motorik dan Perilaku sosial bagi Anak di TK An-Nur PGRI Kota Bima" ini bertujuan untuk: (1) Menumbuhkan dan mengapresiasi kembali permainan tradisonal secara umum, khususnya di Kota Bima; (2) Mengkreatifkan metode pembelajaran bagi guru; (3) Mengembangkan kemampuan motorik dan perilaku sosial pada anak usia dini. Penelitian ini menggunakan pendekatan kualitatif deskriptif. Teknik pengumpulan data yang digunakan adalah, observasi, wawancara dan dokumentasi. Kesimpulan dari penelitian ini yaitu permainan tradisional edukatif yang diterapkan dapat memberikan stimulus atau rangsangan bagi kemampuan motorik dan perilaku sosial anak.
\end{abstract}

Kata kunci: Permainan;Tradisional;Anak; Motorik;Perilaku Sosial

\begin{abstract}
In stimulating a child's motor development, both fine and gross motor skills can use games. Games in learning for children can also foster pleasure, happiness and develop social behavior. Research on the "Educational Traditional Game" Mpaá Ncimi "as a Method for Improving Motor Skills and Social Behavior for Children in An-Nur Kindergarten PGRI Bima City" aims to: (1) Grow and appreciate again traditional games in general, especially in the City of Bima ; (2) Creating a learning method for teachers; (3) Developing motor skills and social behavior in early childhood. This research uses a descriptive qualitative approach. Data collection techniques used are, observation, interview and documentation. The conclusion of this study is that traditional educational games that are applied can provide stimulus or stimulation for motor skills and social behavior of children.
\end{abstract}

Keywords: Games; Traditional; Children; Motor, Social Behavior

Permainan Tradisional Edukatif (Hardiningsih; Akbar; Nurrahmah) 


\section{PENDAHULUAN}

Salah satu kegiatan yang dapat dilakukan untuk meningkatkan kemampuan motorik dan perilaku sosial anak usia dini adalah dengan permainan. Sesuai dengan pasal 1 ayat 14 dalan undang undang no 20 tahun 2003 tentang layanan pendidikan bagi anak usia dini dimana kegiatan yang pembelajaran yang dilakukan pada layanan pendidikan anak usia dini harus mampu memberikan stimulasi bagi anak baik motorik kasar dan halus anak, selain itu juga mampu memberikan rasa senang bagi anak usia dini serta dapat menumbuhkan interaksi sosial antara anak yang satu dengan yang lain. Hal lainnya, kegiatan main yang dilakukan anak dipercaya dapat membuat anak belajar dari proses kegiatan main yang dilakukan anak (Nahdi \& Yunitasari, 2019; Yuliastri, Nur Adiyah, ramdhani, 2018).

Banyak kegiatan main yang dapat dilakukan anak, baik main secara mandiri maupun main secara berkelompok (Mulyasa, 2012). Diantara sekian banyak permain yang dapat dilakukan anak, satu diantaranya adalah permainan tradisional. Mengingat makin terkikisnya permainan tradisional yang dimainkan anak sekarang ini, maka menjadi penting untuk menggaungkan kembali permainan tersebut. Baik dimainkan secara langsung permainan tersebut, maupun di modifikasi untuk kepentingan tertentu. Adapun kegiatan main dengan permainan tradisional pada penelitian ini adalah permainan tradisional edukatif atau permainan tardisional yang telah di modivikasi untuk kepentingan tertentu.

Hal ini dilakukan mengingat manfaat yang ingin di tampilkan dalam penelitian tersebut, maka permainan tradisional pada kesempatan ini, bukan yang ditampilkan sebenarnya, akan tetapi sudah di modivikasi. Hal ini agar nilai dan kebermanfaat dapat ditampilkan pada kegiatan main tersebut. Permainan tradisional pada umumnya dilakukan oleh anak-anak. Meskipun ada juga permainan tradisional yang dilakukan oleh para orang dewasa. Permainan yang dilakukan oleh anak-anak pada dasarnya dilakukan untuk menyenangkan hati dan mengikat kebersamaan serta kerjasama sosial dengan anak-anak lain, tetapi kadangkala permaian dilakukan anak-anak sebagai kegiatan pengisi waktu luang disela-sela kesibukannya.

Permainan tradisional merupakan salah satu bentuk permainan yang dapat dibelajarkan kepada anak usia dini. Dalam permainan baik itu permainan tradisional maupun permainan modern (dengan penggunaan teknologi) seharusnya mengandung proses belajar sensorik maupun motorik. Proses belajar tersebut tidak dapat dipisahkan dari proses mengajar senso-motorik dan perilaku sosial dalam pendidikan bagi anak usia dini. Pembelajaran pada anak usia dini hakikatnya merupakan upaya untuk menjadikan peserta didik belajar. Secara umum tujuan pembelajaran permainan tradisional untuk anak usia dini dapat melibatkan anak untuk berpartisipasi secara aktif dalam kegiatan pembelajaran, selain itu dengan permainan tradisional diharapkan juga dapat mengembangkan kemampuan anak sesuai dengan kebutuhan perkembangan baik sensorik motorik maupun perilaku sosial. Pembelajaran permainan tradisional untuk anak usia dini secara khusus membantu mereka dalam pertumbuhan dan perkembangan jasmani, mental, emosional, dan sosial yang sesuai dengan potensinya melalui program aktivitas permainan yang dirancang khusus dengan hati-hati. Selain itu dengan permainan 
tradisional ini diharapkan dapat membantu peserta didik dalam mengembangkan pengetahuan dan apresiasi terhadap mekanisme tubuhnya sendiri, serta memberikan pemahaman dan menghargai bermacam permainan tradisional yang dapat dinikmatinya baik sebagai peserta maupun sebagai penonton (adawiyah agustina et al., 2015; Nugrahastuti et al., 2012).

Berdasarkan tujuan tersebut, pembelajaran permainan tradisional untuk anak usia dini diharapkan dapat memberi manfaat bagi peserta didik. Melalui program pembelajaran dengan permainan tradisional yang dirancang dan dilaksanakan dengan baik, permianan ini harus dapat: (1) merangsang pertumbuhan dan perkembangan motorik, (2) memengaruhi perkembangan keterampilan gerak, (3) membantu mengembangkan efisiensi koordinasi syaraf otot (neuro muskuler), (4) membantu pengembangan kekuatan, (5) membantu anak dalam beradaptasi dengan anak-anak lain. Hal ini membentuk nalar yang kuat para guru untuk melaksanakan (mempraktekan) konsep-konsep (konstruks) persepsi senso-motorik dalam belajar dengan permianan tradisional.

Berdasarkan hasil wawancara dengan kepala sekolah TK An Nur PGRI Kota Bima pada tanggal 05 Juli 2019 di ruang kepala sekolah TK An Nur PGRI Kota Bima, didapat informasi bahwa sistem pembelajaran dilakukan dalam dua ruangan belajar (rombel), selain itu kegiatan olahraga dilakukan sepekan sekali, yaitu pada hari Sabtu. Penerapan pembelajaran pada anak usia dini di TK An Nur PGRI Kota Bima ini masih minim. Hal ini dikarenakan latar belakang pendidik di TK An Nur PGRI Kota Bima yang beragam. Oleh karena itu dianggap penting untuk melakukan penelitian dengan menerapkan metode pembelajaran dengan permainan tradisional. Hal ini dianggap penting kerena mengingat keberagaman kemampuan motorik dan perilaku sosial anak usia dini yang ada di TK An Nur PGRI Kota Bima tidak sama antara satu dengan yang lain.

Untuk memastikan hasil wawancara tersebut dan menindaklanjutinya, peneliti melakukan observasi lanjutan yang dilaksanakan pada tanggal 16 Juni 2019, dengan mengunjungi semua ruang belajar dan melakukan wawancara dengan guru-guru yang ada di TK An Nur PGRI Kota Bima. Dari observasi lanjutan didapat bahwa pelaksanaan pembelajaran pada anak usia dini dilakukan secara Rombel (Rombongan Belajar), dimana kadang kala digabung antara anak kelompok A dan B. Selain hal tersebut karena mengingat STKIP Taman Siswa yang mempunyai salah satu lokasi di kota yang dekat dengan TK An Nur PGRI Kota Bima, sehingga dianggap perlu untuk melakukan penelitian di sekolah tersebut. Karena masih kurangnya penelitian dan pengabdian yang melibatkan anak usia dini.

Selanjutnya, wawancara dengan salah satu guru kelas TK B1 dan kepala sekolah di TK An Nur PGRI Kota Bima didapat beberapa informasi yaitu: 1) sebagian besar guru yang mengajar di TK An Nur PGRI Kota Bima memiliki latar belakang pendidikan yang bukan dari PAUD (Pendidikan Anak Usia Dini). 2) Pada metode pembelajaran, guru lebih banyak menggunakan metode membaca, menulis dan berhitung (calistung), kurang melakukan inovasi dalam proses pembelajaran. Akibatnya, proses pembelajaran terasa biasa-biasa saja. 3) Kegiatan pembelajaran dengan metode bermain masih jarang dilakukan. Dan 4) Metode 
bermain dengan permainan tradisional masih perlu dilakukan agar pembelajaran bagi anak usia dini bisa lebih termotivasi dan tertarik. Dari berbagai situasi yang dijelaskan, dapat diasumsikan bahwa untuk meningkatkan kemampuan motorik dan perilaku sosial anak usia dini di TK An Nur PGRI Kota Bima guru perlu menambah referensi metode pembelajaran salah satunya dengan memanfaatkan permainan tradisional edukatif, permainan tradisional edukatif disini disebut juga (Mpaá ncimi/mencari jejak yang telah dimodifikasi). Proses pelaksanaan kegiatan permainan tradisional edukatif ini rencananya akan dilakukan di TK An Nur PGRI Kota Bima sebagai layanan Pendidikan Anak Usia Dini (PAUD) dengan keberagaman peserta didik yang kebersediaan memberikan layanan kerjasama dalam bentuk pengabdian dalam tri dharma perguruan tinggi.

Berdasarkan masalah di atas, dipandang perlu melakukan penelitian tentang Permainan Tradisional Edukatif “Mpaá ncimi"untk meningkatkan kemampuan motorik dan perilaku sosial anak usia dini. Oleh karena itu salah satu strategi yang dapat dilakukan oleh peneliti dalam membantu pendidik/guru dalam proses pembelajaran yaitu dengan penerapan metode permainan tradisional edukatif "Mpaá ncimi". Penelitian ini diharapkan dapat menggambarkan serta mendeskripsikan metode pembelajaran bagi guru dalam mengatasi kemampuan motorik dan perilaku sosial anak usia dini. Selain itu, karena dilihat dari masih minimnya penggunaan metode dengan permainan tradisional edukatif pada pembelajaran anak usia dini, tidak menutup kemungkinan mempunyai peserta didik yang belum berkembang kemampuan motorik dan perilaku sosial. Keadaan tersebut menjadi alasan perlunya memanfaatkan potensi kearifan lokal (permainan tradisional "Mpaá ncimi") pada diri calon pendidik/guru terutama. Hal ini juga dapat diberlakukan pada ranah pendidikan (perguruan tinggi) saat ini. Diharapkan, hasilnya dapat membantu menyelesaikan satu fenomena sosial dan pengembangan kompetensi akademik mahasiswa sebagai calon pendidik.

\section{METODE PENELITIAN}

Penelitian ini menggunakan pendekatan kualitatif deskriptif. Teknik pengumpulan data yang digunakan adalah, observasi, wawancara dan dokumentasi. Sedangkan analisis data dalam penelitian ini peneliti menggunakan triangulasi data. Dalam triangulasi data, sumber berupa data informasi dari guru, kepala sekolah dan kegiatan permainan yang diterapkan. Dengan menggunakan metode observasi, wawancara dengan pendidik dan dokumentasi yang dilakukan di TK An-Nur PGRI Kota Bima.

Analisis data dilakukan dengan cara mengorganisasikan data yang diperoleh kedalam sebuah kategori, menjabarkan data kedalam unit-unit, menganalisis data yang seuai dengan masalah penelitian dalam bentuk laporan, dan membuat kesimpulan agar mudah untuk dipahami. Dalam analisis data terbagi menjadi 4 tahapan, yaitu Pengumpulan data, pada tahapan ini peneliti melakukan observasi awal lingkungan penelitian TK An-Nur PGRI Kota Bima dan melakukan pengumpulan data. Peneliti mengumpulkan berbagai informasi yang diperlukan dalam proses pengambilan data atau penelitian. Reduksi data, kegiatan ini peneliti mulai memilah data, mengategorikan, dan membuat abstrak dari catatan lapangan, 
wawancara, dan dokumentasi. Data yang diperoleh merupakan data yang terkait pelaksaan permainan tradisional edukatif "Mpaá ncimi" untuk mengembangkan kemampuan motorik dan perilaku sosial anak. Peneliti menggunakan trianggulasi data/sumber dalam penelitian ini. Dalam trianggulasi data, sumber yang diperoleh melalui guru, kepala sekolah dan kegiatan permainan yang diterapkan. Penggunaan metode observasi, wawancara dengan pendidik dan didokumentasikan yang dilakukan di TK An-Nur PGRI Kota Bima membantu dalam pemilihan data yang relevan selanjutnya mengarahkan pada pemecahan masalah data yang menjawab permasalahan yang diteliti. Penyajian data, dilakukan setelah data selesai direduksi atau dirangkum. Data yang diperoleh dari hasil observasi, wawancara, dan dokumentasi dianalisis kemudian disajikan dalam bentuk cacatan (wawancara, lapangan, dan dokumentasi). Kesimpulan, berdasarkan data yang telah direduksi dan disajikan, peneliti membaut kesimpulan yang didukung dengan bukti yang kuat pada tahap pengumpulan data.

\section{HASIL DAN PEMBAHASAN}

Berdasarkan data hasil penelitian yang telah dilakukan, baik dari hasil wawancara dengan pendidik, observasi maupun dokumentasi yang didapat peneliti, maka penerapan permainan tradisional edukatif "Mpaá ncimi" terhadap kemampuan motorik dan perilaku sosial anak adalah sebagai berikut:

\section{Mengidentifikasi kemampuan motorik dan perilaku sosial anak melalui kegiatan permainan tradisional edukatif.}

Berdasarkan hasil penelitian yang diperoleh bahwa kemampuan motorik dan perilaku sosial anak di TK An-Nur PGRI Kota Bima melalui kegiatan permainan tradisional edukatif "Mpaá ncimi" yang telah diterapkan maka dapat dijadikan sebagai acuan atau sumber dalam meningkatkan kemampuan motorik dan perilaku sosial anak, hal ini saling berkaitan antara permainan tradisional edukatif, kemampuan motorik serta perilaku sosial anak. Melalui kegiatan permainan tradisional edukatif ini, anak dilatih mengembangkan keaktifan motorik halus (memegang, menyentuh, dan lain sebagainya), motorik kasar (berlari, melompat, dan lain sebagainya) anak juga dilatih untuk dapat bekerjasama dengan anak lainnya. Jadi, kegiatan tersebut dapat dikatakan saling melengkapi, ada keterkaitan antara permainan tradisional, kemampuan motorik, dan perilaku sosial anak.

Mengembangkan kemampuan motorik dan perilaku sosial anak melalui kegiatan permainan tradisional edukatif "Mpaá ncimi".

Berdasarkan hasil penelitian yang telah dilakukan di TK An-Nur PGRI Kota Bima dalam mengembangkan kemampuan motorik dan perilaku sosial anak yakni dapat terlihat dengan jelas anak semakin aktif dan senang. Hal ini terlihat dari semangat dan antusias anak dalam mengikuti kegiatan permainan yang dilakukan, walaupun masih banyak kekurangan yang harus diperbaiki. Di sisi lain, semangat dan kerjasama yang telah ditunjukkan anak pada TK An-Nur PGRI Kota Bima dapat menjadi acuan awal untuk meningkatkan kemampuan dan karakter 
lainnya yang lebih baik lagi kedepannya dengan permainan tradisional lain yang lebih beragam.

Kemampuan motorik dan perilaku sosial anak yang dikembangkan melalui kegiatan permainan tradisional edukatif merupakan langkah awal dalam meningkatkan solidaritas kerjasama anak. Hal ini sesuai dengan yang disampaikan Syamsiatin (2108: 1.3) permainan dapat membuat anak menjadi semangat, senang, fokus serta merupakan kebutuhan dalam proses perkembangan anak. Adapun hal yang perlu diperhatikan dalam meningkatkan kemampuan motorik dan perilaku sosial anak, yakni memastikan bahwa melalui kegiatan permainan anak dapat melakukan perlibatan langsung baik dengan benda maupun dengan orang. Selain itu permainan juga merupakan kegiatan aktif yang memberikan kesempatan pada anak untuk melakukan eksplorasi pada lingkungan sekitarnya. Melalui permainan anak juga dapat membangun pengetahuan dan keterampilan. Lebih lanjut, melalui kegiatan permainan anak diajarkan untuk berinteraksi dengan teman sebaya bahkan dengan teman beda usia. Kegiatan permaianan, juga membuat anak merasakan emosinal yang berbeda, mereka merasakan kesenangan, kemandirian, kerjasama, dan tanggung jawab atas pilihan pilihan yang dilakukan (Rachawati, 2018: 7.3).

Kemudian dalam meningkatkan kemampuan motorik dan perilaku sosial anak di taman kanak kanak, diperlukan; (1) kemampuan motorik, antara lain dengan merangsang perkembangan fisik anak dengan keterampilan lokomotor, melatih anak melakukan keseimbangan ketika bergerak, melatih anak melakukan tendangan, lompat, lempar dan tangkapan objek, mengontrol otot otot kecil, serta koornasi mata dan tangan. (2) Perilaku sosial, antara lain dengan melatih anak beradaptasi, melatih anak mengenal dan memahami perasaan diri sendiri, mempertanyakan haknya, mengajarkan anak mengikuti aturan serta melatih anak untuk dapat bermain bersama.

Selanjutnya, untuk untuk mendukung kemampuan motorik dan perilaku sosial anak di TK An-Nur PGRI Kota Bima bisa menggunakan permainan tradisional edukatif lainnya. Adapun permainan tradisional lain yang dapat mendukung kemampuan motorik dan perilaku sosial anak, seperti: engklek, bentengan, lompat tali dan lain sebagainya. Permaianan tradisional sebagai metode pembelajaran bagi anak, juga mengandung nilai seni dan budaya yang bisa dikenalkan pada anak. Untuk itu, memanfaatkan permainan tradisional pada proses pembelajaran juga merupakan kegiatan yang cukup efektif dan bervariatif bagi anak, sehingga anak tidak merasa bosan dan jenuh. Hal ini dapat dilakukan oleh guru pada layanan pendidikan tersebut dalam meningkatkan kemampuan motorik dan perilaku sosial pada anak usia dini.

\section{Kendala dalam Meningkatkan Kemampuan Motorik dan Perilaku Sosial Anak}

Berdasarkan hasil wawancara di TK An-Nur PGRI Kota Bima, maka dapat diketahui bahwa kendala dalam meningkatkan kemampuan motorik dan perilaku sosial anak adalah, (1) belum terlaksana identifikasi tahap "screening" yang mengentaskan massal (peserta permainan dalam jumlah banyak) dengan menggunakan tes kelompok dan tahap seleksi atau mengidentifikasi dengan 
menggunakan tes individual yang memungkinkan pengukuran yang lebih teliti dan tepat yang belum terlaksana. (2) Belum optimalnya pelaksanaan kegiatan permainan tradisional edukatif, hal ini dikarenakan pengikut sertaan semua peserta didik (jumlah peserta didik terlalu banyak), sehingga kesulitan memantau satu persatu anak didik. Sebagaimana hasil pelaksanaan kegiatan penerapan permainan tradisional edukatif. (3) Pelaksanaan kegiatan pembelajaran dengan menerapkan permainan tradisional dianggap jarang dilakukan atau belum pernah diterapkan sebelumnya di TK An-Nur PGRI Kota Bima sehingga pendidik juga belum memahami betul alur pelaksaan kegiatan dengan penerapan permainan tradisional edukatif (Wijayanto \& Siradj, 2017; Yudiwinata \& Handoyo, 2014).

\section{KESIMPULAN}

Kemampuan motorik dan perilaku sosial merupakan aspek tumbuh kembang yang biasa terjadi pada setiap anak, sehingga perlunya stimulus atau rangsangan dalam mengoptimakan kemampuan tersebut. Adapun peningkatan kemampuan motorik dan perilaku sosial anak di TK An-Nur PGRI Kota Bima, meliputi: identifikasi kemampuan motorik dan perilaku sosial anak yang diperoleh dari informasi yang didapat dari pendidik dan penerapan permainan tradisional edukatif, belum terlaksananya identifikasi tahap "screening". Kemudian untuk mengembangkan kemampua n motorik dan perilaku sosial anak di TK An-Nur PGRI Kota Bima bisa menggunakan permainan tradisional edukatif lainnya. Adapun permainan tradisional lain yang dapat mendukung kemampuan motorik dan perilaku sosial anak, seperti: engklek, bentengan, lompat tali dan lain sebagainya. Permainan tradisioanal edukatif dapat digunakan sebagai metode pembelajaran bagi anak, karena mengandung nilai seni dan budaya yang bisa dikenalkan pada anak anak sejak dini. Selain itu, permainan tradisional merupakan kegiatan yang cukup efektif dan bervariatif bagi anak, sehingga anak tidak merasa bosan dan jenuh. Lebih lanjut, pendidik dapat memodifikasi kegiatan/jenis permainan yang dapat meningkatkan kemampuan motorik dan perilaku sosial pada anak usia dini.

\section{DAFTAR PUSTAKA}

adawiyah agustina, R., shofa ilhami, B., \& Najamuddin. (2015). Pengembangan Model Permainan Tradisional Engklek Edukatif Dalam Mengembangkan Kemampuan Motorik Kasar Dan Kognitif Anak Usia 5-6 Tahun. 5-6.

Dewi, A. R. T. (2018). Pengaruh Keterlibatan Orangtua Terhadap Perilaku Sosial Emosinal Anak. Jurnal Golden Age, 2(02), 66-74.

Kurniati, E. (2016). Permainan tradisional dan perannya dalam mengembangkan keterampilan sosial anak. Kencana.

Fitriani, R., \& Adawiyah, R. (2018). Perkembangan Fisik Motorik Anak Usia Dini. Jurnal Golden Age, 2(01), 25-34. 
Khasanah, I., Prasetyo, A., \& Rakhmawati, E. (2011). Permainan tradisional sebagai media stimulasi aspek perkembangan anak usia dini. PAUDIA: Jurnal Penelitian dalam Bidang Pendidikan Anak Usia Dini, 1(1).

Mulyasa, H. E. (2012). Manajemen PAUD. Bandung: Rosdakarya

Nahdi, K., \& Yunitasari, D. (2019). Inside-outside circle: An early childhood language and literacy development method. International Journal of Innovation, Creativity and Change, 5(6), 325-335.

Munawaroh, H. (2017). Pengembangan model pembelajaran dengan permainan tradisional engklek sebagai sarana stimulasi perkembangan anak usia dini. Jurnal Obsesi: Jurnal Pendidikan Anak Usia Dini, 1(2), 86-96.

Nugrahastuti, E., Puspitaningtyas, E., \& Puspitasari, M. (2012). Nilai-Nilai Karakter Pada Permainan Tradisional. Prosiding Seminar Nasional Inovasi Pendidikan Inovasi Pembelajaran Berbasis Karakter Dalam Menghadapi Masyarakat Ekonomi ASEAN, 265-273. https://jurnal.fkip.uns.ac.id/index.php/snip/article/view/8942

Repubik Indonesia. (2014). Undang-Undang R. I. Nomor 20 Tahun 2003 tentang SISDIKNAS dan Peraturan Pemerintah R. I. Tahun 2013 tentang Standar Nasional Pendidikan serta Wajib Belajar. Bandung: Citra Umbara

Roostin, E., \& Aprilianti, R. (2018). Pengembangan Permainan Tradisional Dakuca Untuk Menstimulasi 6 Aspek Perkembangan Pada Anak Usia Dini. Jurnal Golden Age, 2(01), 13-24.

Saputra, N. E., \& Ekawati, Y. N. (2017). Permainan tradisional sebagai upaya meningkatkan kemampuan dasar anak. Jurnal Psikologi Jambi, 2(2), 47-53.

Wijayanto, P. W., \& Siradj, Y. (2017). The Educational Game "Indonesian Tribes" for the Kindergarten Students. IJPTE : International Journal of Pedagogy and Teacher Education, 1(1), 27-36. https://doi.org/10.20961/ijpte.v1i1.8456

Yudiwinata, H. P., \& Handoyo, P. (2014). Permainan Tradisional dalam Budaya dan Perkembangan Anak. Paradigma, 02, 1-5.

Yuliastri, Nur Adiyah, ramdhani, sandy. (2018). Pembelajaran tematik integratif berbasis kearifan lokal untuk anak usia dini : jurnal golden age 3(1), 44-58. 